\title{
KOD YASA-ÇERÇEVE YASA AYRIMI ÜZERİNE
}

\author{
Dr. Fahri BAKIRCI*
}

Yasa kavramı, çeşitli açılardan sınıflandırılabilir ${ }^{1}$ : Geçici yasa, sürekli yasa, süreli yasa ${ }^{2}$, kod yasa, temel yasa, çerçeve yasa vs. Norm koyma tekniği bakımından, bu ayrımların her birinin büyük önemi vardır. $\mathrm{Bu}$ bağlamda, "kod yasa, temel yasa ve çerçeve yasa" kavramları çoğu kez birbirine karıştırılan ve bu nedenle bazı ikincil yanlışlıkların türemesine neden olan kavramlardır. Bu kavramsal karışıklık, kimi kez, kavramların farklı anlamlarda kullanılmasından, kimi kez de kavramlar arasındaki sınırın belirginleştirilmemiş olmasından kaynaklanmaktadır. Gerçekten de çerçeve yasa, kimi zaman daha kapsayıcı olan yasa ya da temel yasa anlamında kullanılmaktadır. Kimi zaman temel yasa ile kod yasa aynı anlamda kullanılmakta ve çerçeve yasa kavramı bunların karşısına konmaktadır. Dolayısıyla, çerçeve yasa-kod yasa ayrımının ortaya konabilmesi için öncelikle temel yasa ile kod yasa arasındaki farkın açıklığa kavuşturulması gerekir. $\mathrm{Bu}$ amaçla, öncelikle, ülkemizdeki temel yasa kavramının ve uğradığı değişikliklerin kısaca açıklanmasında yarar vardır.

\footnotetext{
* TBMM İçişleri Komisyonu Üyesi

${ }^{1}$ Burada hemen belirtmek gerekir ki, bu makalede yasanın geniş anlamı kullanılmaktadır. Doktrinde maddi yasa "umumi, mücerret, daimi, emredici ve makabline şümulü olmayan objektif hak kaidelerinin hey'eti umumiyesi" ya da "genel, nesnel ve kişilik dișı hukuk kurallarının bütünü” biçiminde tanımlanmaktadır(Ayrıntı için bakınız BAKIRCI, 2000: 394395). Burada yasaların, norm koyma tekniği açısından sınıflandırılması söz konusu olduğundan, TBMM tarafından çıkarıldıkları için yasa adını alan metinler de inceleme kapsamındadır. Diğer bir anlatımla, yasa sözcüğünden burada hem maddi hem de biçimsel anlamda yasayı anlamak gerekir. Bu nedenle, bu makalede, Teziç’in yaptığı, "Kanun, genel olarak, parlamentonun öngörülen yasama usullerine göre kabul ettiği bir işlemdir (2003: 390)." biçimindeki tanımın ya da Gözler'in söz ettiği "şekli ya da organik kriter"in (GÖZLER, 2004: 210-211) kullanıldığ varsayılmalıdır.

${ }^{2}$ Geçici yasa-süreli yasa-sürekli yasa ayrımı başka bir makalede incelenmiş olduğundan burada bu konuya girilmeyecektir (Bakınız: BAKIRCI, 2004: 38-41).
} 
16. 5. 1996 tarihli ve 424 sayılı TBMM Kararı ile 1973 İçtüzüğüne eklenen maddelerden biri "Temel Kanunlar" başlıklı 91 inci maddedir. Madde metni şöyledir:

“Temel kanunlarl ve İçtüzüğü bütünüyle veya kapsaml olarak değiştiren veya yürürlüğe koyan tasarı veya tekliflerin Genel Kurulda görüşülmesinde uygulanacak özel görüşme ve oylama usulü tespitine Hükümetin, esas komisyonun veya grupların teklifi, Danışma Kurulunun oybirliği ile önerisi üzerine Genel Kurulca karar verilebilir."

$\mathrm{Bu}$ kural, Danışma Kurulunda oybirliği sağlanamadığından işlerlik kazanamamış ve TBMM'nin 7.2.2001 günlü, 713 sayılı kararıyla şu biçimde değiştirilmiştir:

"Temel kanunları, Iç̧ü̈züğü ve ülkenin ekonomik ve teknolojik gelişimi ile doğrudan ilgili yeniden yapılanma kanunlarını bütünü ile veya kapsaml olarak değiștiren veya yürürlüğe koyan tasarı veya tekliflerin Genel Kurulda görüsülmesinde uygulanacak özel görüşme ve oylama usulü ile maddeler üzerinde önerge verilip verilemeyeceğinin tespitine Hükümetin, esas komisyonun veya grupların teklifi, Danışma Kurulunun önerisi üzerine Genel Kurulca karar verilebileceği gibi, Danışma Kurulunda oybirliği sağlanamaması halinde siyasi parti gruplarının önerisi üzerine Genel Kurulca üye tamsayısının beşte üç çoğunluğunun oyu ile de karar verilebilir."

Buradaki ana değişiklik, "Danışma Kurulunun oybirliği ile önerisi" zorunluluğunun, "Danışma Kurulunda oybirliği sağlanamaması halinde siyasi parti gruplarının önerisi üzerine Genel Kurulca üye tamsayısinın beşte üç çoğunluğunun oyu ile de karar verilebil"mesi olanağına dönüştürülmesidir. Böylece temel kanunun belirlenmesinde bütün siyasi parti gruplarının uzlaşamadığı durumlarda, iktidar partisi grubu/gruplarına temel kanunu belirleme yetkisi verilmektedir.

Ancak madde, Anayasa Mahkemesi'nin 31.1.2002 günlü, Esas: 2001/129, Karar: 2002/24 sayılı kararıyla iptal edilmiştir. Anayasa Mahkemesi sözkonusu kararında şunları söylemektedir:

"Dava konusu 91. maddeyle temel kanunları, İçtüzüğ̈̈ ve ülkenin ekonomik ve teknolojik gelişimi ile doğrudan ilgili yeniden yapılanma kanunlarını bütünüyle veya kapsamlı olarak değiștiren veya yürürlüğe koyan tasarl ve tekliflerin Genel Kurul'da görüsülmesinde uygulanacak özel görüşme ve oylama usulünün çerçevesi çizilip esasları belirlenmemiş, bunun, tasarı ve tekliflerin her biri için özel olarak Genel Kurul'ca saptanmast öngörülmüş̧ür. Böylece, sözü edilen tasarl ve tekliflerin tümü veya 
maddeleri hakkında görüşme yapılıp yapılmayacağl, soru-cevap işlemine olanak săglanıp săglanmayacă̆l, ne kadar süre ile konuşma yapılacağı, önerge verilip verilmeyeceği, tasarl veya tekliflerin tümünün oylanmasindan önce, maddelerinin oylanıp oylanmayacă̆l gibi hususlar Genel Kurul'ca karara bağlanacak ve bu hususlar sadece belirli bir tasarı veya teklifin görüsme ve oylama usulü için geçerli olacaktır./ Anayasa'nın 2. maddesinde belirtilen hukuk devleti, siyasal iktidart sintrlamak ve devlet faaliyetlerini kurallara bağlamakla istikrara da hizmet eder. Bu istikrarın özü ise hukuki güvenlik ve öngörülebilirliktir. Bunu gerçekleştirmenin başlıca yolu ise kural konulmasını gerektiren durumlarda bunların genel, soyut, anlaşllabilir ve sinırlarının belirli olmasını să̆lamaktır./ Öte yandan, milletvekillerinin Anayasa'nın 87. maddesinde belirtilen görevlerini yerine getirebilmeleri ve yetkilerini kullanabilmeleri yasama faaliyetlerine etkili biçimde katılmaları ile olanaklıdır. Bunu sağlamanın ön koşulu ise Meclis çalışmalarını düzenleyen Iç̧ü̈zük kurallarının "belirlilik", "genellik", "soyutluk" ve "öngörülebilirlik” özelliklerine sahip olmasıdır./ Dava konusu 91. maddede belirtilen "temel kanun" ve "ülkenin ekonomik ve teknolojik gelişimi ile doğrudan ilgili yeniden yapılanma kanunları"nın kapsamına açılılı getirilmemesi, pek çok yasanın bu kapsam içinde düşünülmesine neden olabilecektir. Ayrıca, maddede öngörülen her tasar veya teklife özgü biçimde uygulanacak görüşme ve oylama usulü önceden bilinemeyeceğinden objektiflik sağlanamayacaktır./Bu durumda, dava konusu kural, belirlilik, genellik, soyutluk ve öngörülebilirlik özellikleri, taşımaması nedeniyle yasama yetkisinin amacına uygun biçimde kullanılmasına elverişli olmadı̆̆ gibi hukuk devleti ilkesiyle de bağdaşmamaktadır./Açıklanan nedenlerle kural, Anayasa'nın 2. ve 87. maddelerine aykırıdır. Íptali gerekir."

TBMM, 10. 04. 2003 tarih ve 766 sayılı Kararının çerçeve 4 üncü maddesiyle, iptal edilmiş bulunan 91 inci maddeyi yeniden düzenlemiştir. 766 sayılı Kararla kabul edilen madde şöyledir:

"Temel kanunlarl ve Iç̧üzüğü bütünüyle ve kapsamll olarak değiştiren veya yürürlüğe koyan tasarı veya tekliflerin Genel Kurulda bölümler halinde görüşülmesine ve her bölümün hangi maddelerden oluşacağına, Hükümetin, esas komisyonun veya grupların teklifi, Danışma Kurulunun önerisi üzerine Genel Kurulca karar verilebileceği gibi, Danışma Kurulunda oy birliği sağlanamaması halinde siyasî parti gruplarının önerisi üzerine Genel Kurulca üye tam sayısının beşte üç çoğunluğunun oyu ile karar verilebilir. Bu takdirde bölümler, maddeler okunmaksızın 
ayrı ayrı görüşülür ve oylanır. Bölümler üzerinde verilen önergelerin kabulü halinde o bölüm kabul edilen önergeler ile birlikte oylanır./ Bölümlerin görüşülmesinde maddelerin görüşülmesine ilişkin hükümler uygulanır."

$\mathrm{Bu}$ düzenleme de Anayasa Mahkemesinin 29.4.2003 günlü, Esas: 2003/30, Karar: 2003/38 sayılı kararıyla iptal edilmiştir. Kararda belirtildiği gibi, dava konusu 91. maddede, daha önce iptal edilen düzenlemeden farklı olarak, "ülkenin ekonomik ve teknolojik gelişimi ile doğrudan ilgili yeniden yapılanma kanunları" ibaresi yer almamış, özel görüşme ve oylama usulü, temel kanunların ve İçtüzügün bütünüyle veya kapsamlı olarak değiştirilmesiyle sınırlı tutulmuş ve eski düzenlemede olduğu gibi temel kanun tanımı yapılmamıştır. Ayrıca, belirtilen metinlerin bölümler halinde görüşülmesine ve her bölümün hangi maddelerden oluşacağına Genel Kurul tarafindan karar verilmesine ve bu durumda bölümlerin maddeler okunmaksızın ayrı ayrı görüşülüp oylanmasına, bölümler üzerinde verilen önergelerin kabulü halinde de o bölümün kabul edilen önergeler ile birlikte oylanmasına olanak tanınmıştır. Yine eski düzenlemeden farklı olarak, bir yasanın temel yasa olarak kabul edilebilmesi için, (Danışma Kurulunda oybirliği sağlanamaması halinde) siyasal parti grubu önerisinin üye tamsayısının beşte üç çoğunluğu ile kabul edilmesi koşulu getirilmiştir. Böylece bir yasanın temel yasa olmasına, genel kurulun ağırlıklı çoğunluğu karar verilmiş olacak ve temel yasanın belirlenmesi konusunda kısmi bir uzlaşma sağlanmış olacaktır. Anayasa Mahkemesi sözkonusu iptal kararında şunları söylemektedir:

"91. madde ile temel kanunlara ilişkin tasarl ve tekliflerin görüsülme ve oylanmasinda özel bir usul benimsenerek Genel Kurul'da bölümler halinde görüşülmesi ve her bölümün hangi maddelerden oluşacağ hususunun Genel Kurul'un kararına bağll tutulmasinin öngörülmesi, bu tasarl ve tekliflerin nitelik ve nicelik bakımından geniş kapsaml olduğunu göstermektedir. Bu bağlamda, bir hukuk dalını sistematik olarak bütünüyle veya kapsaml olarak değiştirecek biçimde genel ilkeleri içermesi; kişisel veya toplumsal yaşamın büyük bir bölümünü ilgilendirmesi; kendi alanındaki özel kanunların dayandiğl temel kavramlar göstermesi, özel kanunlar arasında uygulamada ahenk sağlaması, düzenlediği alan yönünden bütünlüğ̈̈nün ve maddeler arasindaki bağlantıların korunması zorunluluğunun bulunması; önceki yasalaşma evrelerinde de özel görüssme ve oylama usulüne bağl tutulması gibi özellikleri taşıması bir yasanın temel yasa olarak kabulünün göstergesidir. Bu tür kapsaml yasal düzenlemelere ilişkin tasarı ve tekliflerin, madde sayllarının fazlalı̆̆ nedeniyle Genel Kurul çalışmalarının aksamadan yürütülebilmesi için özel görüşme ve oylama usulüne bağll tutulmalarına gerek duyulabilir./ 
Belirtilen durumlar dışında özel görüşme ve oylama usulünün yayginlaştırılmasina neden olabilecek düzenlemeler ise, milletvekillerinin yasama etkinliklerine gereği gibi katılmalarına olanak vermeyeceğinden demokratik hukuk devleti anlayışı ile bağdaşmayacă̆ı gibi Anayasa'nın Türkiye Büyük Millet Meclisi'nin görev ve yetkileriyle ilgili 87. maddesi yönünden de sakıncalar doğurur. Bu tür anayasal sorunlara neden olunmamast için özel görüşme ve oylama usulüne ilişkin esasların açıklıkla belirlenmesi gerekir./ Öte yandan, dava konusu düzenleme ile kimi tasarı ve tekliflerin bölümler halinde oylanması öngörülerek maddelerin ayrı ayrı oylanması engellenmektedir. Böylece, milletvekillerinin bir bölüm içinde yer alan kimi maddeler için ret ya da kabul yönünde oy kullanmalarına olanak tanınmamaktadır. Oysa, oy kullanma yetkisi demokratik olmayan yöntemlerle sinırlandırıldı̆̆ında, yasama işlevinin amacı doğrultusunda yerine getirildiğinden söz edilemez./ Temel kanunların veya içtüzüğ̈̈n bir kaç maddesinin değiştirilmesinin öngörülmesi kapsamlı değişiklik olarak nitelendirilemeyeceğinden, bununla madde saylsı gözetildiğinde görüşülmesi uzunca bir süre alabilecek yasal düzenlemelerin amaçlandiğı anlaşılmaktadır./Açıklanan nedenlerle, dava konusu kural Anayasa'nın 2. ve 87. maddelerine aykırıdır. Iptali gerekir.

Anayasa Mahkemesinin bu ikinci iptal kararından sonra yeni bir değişiklik teklifi Anayasa Komisyonunda görüşülerek Genel Kurula gönderilmiştir ${ }^{3}$. Komisyonda kabul edilen yeni düzenleme şöyledir:

"Kapsamlı kanunların görüşülmesi

Madde 91. - Toplumsal hayatın geniş bir alanını düzenleyen ve kapsayan kuralları bir araya getiren, içerdiği hükümler nedeniyle kendi alanindaki mevzuata uyulmasl gereken usulve esaslar ile bu alanda mevzuatın yönelmesi gereken esaslar sistematik ve belirli bir düzen içerisinde gösteren, o alandaki kanunlar arasında ve bunların uygulanmasinda birlikteliği sağlamay amaçlayan Kanunların ve İçtüzüğ̈̈n, en az 40 maddesini değiştiren veya yürürlüğe koyan tasarl veya tekliflerin Genel Kurulda görüşülmesinde uygulanacak özel görüşme ve oylama usulü tespitine, Hükümetin, esas komisyonun veya grupların teklifi, Danışma Kurulunun oybirliği ile önerisi üzerine Genel Kurulca karar verilebilir./Danışma Kurulunda oybirliği sağlanamaması halinde, bu kapsamdaki kanunların bölümler halinde görüsülmesine ve her bölümün en çok 15

\footnotetext{
${ }^{3} \mathrm{Bu}$ Teklifin Komisyonda görüşülmesi sırasında Anayasa Mahkemesinin 29.4.2003 günlü, Esas: 2003/30, Karar: 2003/38 sayılı kararının gerekçesi henüz açıklanmamıştır.
} 
maddeyi geçmemek kaydıyla hangi maddelerden oluşacağına hükümetin, esas komisyonun veya grupların teklifi üzerine Genel Kurulca karar verilebilir. Bu takdirde bölümler, maddeler okunduktan sonra ayrı ayr görüşülür ve bölümdeki maddeler ayrı ayrı oylanır. Bölümlerin görüşülmesinde ve önerge sayısı ile işlemlerinde, madde hakkındaki hükümler uygulanır. Ancak, bölümler üzerindeki önergeler sadece veriliş sırasina göre okunur ve işlemleri yapılır. Bölümler üzerinde birden fazla madde değişikliğini içeren önergeler verilebilir, bu önergelerdeki her madde hakkındaki değişiklikler ayrı ayrı oylanır. 81 inci maddenin diğer hükümleri saklıdır."

Görüldüğü gibi yeni düzenlemede maddenin başlığı da "temel yasa" olmaktan çıkarılmış ve "temel yasa"nın ad1 "kapsamlı yasa"ya dönüş̧ürülmüştür. Bir yasanın kapsamlı yasa sayılabilmesi için en az 40 maddeli olması önkoşulu getirilmiştir. Ancak bu maddenin Genel Kurulda görüşülmesi sırasında, Anayasa Mahkemesinin yukarıda belirtilen 29.4.2003 günlü, Esas: 2003/30, Karar: 2003/38 sayılı kararının gerekçesi açıklandığından maddenin anayasaya aykırılığını gidermek bakımından, bu düzenlemeden vazgeçilmiş ve Anayasa Mahkemesinin çizdiği çerçeve, tanım olarak olduğu gibi maddeye aktarılmıştır. Anayasa Mahkemesi Kararı dikkate alınarak hazırlanan ve TBMM'nin 30/06/2005 tarih ve 855 say1l Kararıyla kabul edilen yeni düzenleme şöyledir ${ }^{4}$ :

"Temel Kanunlar

Madde 91. - a) Bir hukuk dalını sistematik olarak bütünüyle veya kapsamlı olarak değiştirecek biçimde genel ilkeleri içermesi; kişisel veya toplumsal yaşamın büyük bir bölümünü ilgilendirmesi; kendi alanındaki özel kanunların dayandığ temel kavramları göstermesi, özel kanunlar arası maddeler arasındaki bağlantıların korunmasi zorunluluğunun bulunmasi; önceki yasalaşma evrelerinde de özel görüşme ve oylama usulüne bağlı tutulması gibi özellikleri taşlyan kanunları ve İçtüzügü bütünüyle veya kapsaml olarak değiştiren veya yürürlüğe koyan tasarı veya tekliflerin Genel Kurulda bölümler halinde görüşülmesine ve her bölümün en çok otuz maddeyi geçmemek kaydiyla hangi maddelerden oluşacağına hükümetin, esas komisyonun veya grupların teklifi, Danışma Kurulunun oybirliği ile önerisi üzerine Genel Kurulca karar verilebilir. Bu takdirde bölümler, maddeler okunmaksızın maddenin görüşülmesindeki usule göre ayrı ayrı görüşülür ve bölümdeki maddeler ayrı ayrı oylanır./Milletvekilleri, esas komisyon veya hükümet değişiklik önergeleri verebilir. Milletvekilleri tarafindan, Anayasaya aykırılık önergeleri dahil her

\footnotetext{
${ }^{4} \mathrm{Bu}$ Makale yayınlandığı sırada yürürlükte olan düzenleme budur.
} 
madde için iki önerge verilebilir./Bölümler üzerindeki soru-cevap süresi onbeş dakika ile sinırlıdır./ 81 inci maddenin diğer hükümleri saklıdır./ b) Danışma Kurulunda oybirliği sağlanamaması halinde siyasi parti gruplarının önerisi üzerine de (a) bendinde belirtilen yasama yönteminin uygulanmasina Genel Kurulca karar verilebilir. ${ }^{\prime 5}$

Özetle 1996 yılında İçtüzüğe eklenen temel yasa düzenlemesi işlerlik kazanamadığından 2001 yılında değişikliğe uğratılmış ve 2002 yılında Anayasa Mahkemesi tarafından iptal edilmiştir. Madde 2003 yılında yeniden düzenlenmiş ve ikinci kez iptal edilmiştir. 2005 yılında dördüncü kez kabul edilen ve halen yürürlükte olan düzenleme Anayasa Mahkemesinde görüşülmektedir.

Sabuncu, temel yasa, içtüzük ve kapsamlı değiş̧iklik getiren bazı yasaların uzun ve ayrıntılı olabileceklerini; dolayısıyla bunların Genel Kurulda görüşülmesinin çok zaman alabileceğini ve bu nedenle de bu yasaların özel görüşme yöntemiyle görüşülmesine izin verildiğini belirtmektedir ( 2002: 187). Gerçekten de maddenin 1996 yılından 2005 yılına kadar olan serüveni dikkatlice incelendiğinde, amacın başlıkta belirtildiği gibi temel yasaların görüşülmesi olmadığı görülmektedir. Bu görüşme yönteminin uygulanmasına neden olan yapılacak değişikliğin uzun bir görüşme süresini gerektirip gerektirmediğidir. Yukarıda aktarılan Anayasa Komisyonunun kabul ettiği metinde bu durum çok açı görülmektedir. Nitekim Komisyon metninde maddenin başlı̆g 1 da "temel yasa" yerine "kapsaml yasa" olarak değiştirilmiştir. Buradaki amaç, özel önemdeki bir yasanın, özel görüşme yöntemiyle görüşülmesini sağlamak değildir. Örneğin zorunlu temel eğitimin beş yıldan sekiz yıla çıkarılmasını öngören bir yasa, çok önemli bir yapısal dönüşüm yasasıdır. Ancak yukarıdaki İçtüzük kuralları, bu yasanın özel görüşme yöntemiyle görüşülmesine olanak tanımamaktadır.

$\mathrm{Bu}$ konuda akıllarda soru işareti kalmaması için Fransa'daki "organik yasa ${ }^{6 "}$ (loi organique) kavramına kısaca göz atmakta yarar vardır. Fransa' da anayasa değişikliklerine ilişkin yasalar ile olağan yasalar arasında üçüncü bir yasa türü vardır. Organik yasa olarak adlandırılan bu yasalar, hem anayasa değişikliklerine ilişkin yasalardan, hem de olağan yasalardan farklı bir yöntemle görüşülürler. Genellikle kamu güçlerinin örgütlenişine ve işleyiş̧ine ilişkin olan bu yasalar, aslında bir tür anayasa kuralı niteliğindedir.

\footnotetext{
${ }^{5}$ Bu maddenin anayasaya aykırı olduğu savıyla da Ana Muhalefet Partisi tarafından Anayasa Mahkemesine başvurulmuş ve maddenin yürürlüğünün durdurulması istenmiştir. Anayasa Mahkemesi henüz kararını açıklamamıştır.

${ }^{6}$ Gürbüz, Fransızcası "loi organique" olan ve İngilizceye "organic act" biçiminde çevrilen kavramı, "bütünsel yasa" biçiminde çevirmektedir. Bütünsel yasa, "loi organique" kavramını karşılamamaktadır. Bu nedenle bu makalede Eroğul'un kullandığı "organik yasa" biçimindeki çeviri kullanılmıştır.
} 
Zaten, organik yasa çıkarılabilmesi için anayasada açı bir hüküm bulunması zorunludur. Diğer bir anlatımla, organik yasa sadece anayasanın yetki verdiği konularda çıkarılabilmektedir. Örneğin Fransız Anayasasının 25. maddesi, meclislerin görev süresinin, üye sayısının, ödeneklerinin seçilme koşullarının, seçilmeye engel durumların ve üyelikle bağdaşmayan işlerin organik bir yasayla belirleneceğini öngörmektedir. Ülkemizdeki temel kanundan farklı olarak, organik yasaların görüssme yöntemi de Anayasayla belirlenmiş durumdadır. Anayasanın 46 . maddesine göre sunulmalarından itibaren 15 gün geçmedikçe görüşülemezler. İki meclis arasında herhangi bir anlaşmazlık çıkması durumunda "mekik" yoluna gidildiğinde, millet meclisinin son kararı verebilmesi için üye tamsayısının salt çoğunluğunun oyu gereklidir. Senatoyu ilgilendiren ya da Fransa'da oturan Avrupa Birliği vatandaşlarına seçimlerde seçme ve seçilme hakkı verilmesine ilişkin organik yasalarda her iki meclisin aynı metin üzerinde anlaşması zorunluluğu bulunmaktadır. $\mathrm{Bu}$ yasalarda, yasamanın yürütmeyi yetkilendirmesi olanaksızdır. Organik yasalar, yayınlanmadan önce Fransız Anayasa Konseyinin öndenetimine sunulurlar ${ }^{8}$ (EROĞUL, 1997: 142-143). Burada dikkat edilecek olursa, organik yasanın ne olduğu anayasa tarafından tanımlanmıştır. Eroğul'un dediği gibi, organik yasalar "genellikle, kamu örgütlerinin örgütlenişine ve işleyişsine ilişkin"dirler (1997: 142-143). Oysa, TBMM İçtüzüğünde, temel kanunlar tek tek sayılmamış, genel bir tanımlama yapılmıştır. Örneğin 2001 yılında kabul edilen 713 sayılı kararda 91. madde şöyledir?'

(1) Temel yasaları,

(2) İçtüzüğü,

(3) Ülkenin ekonomik ve teknolojik gelişimi ile ilgili yeniden yapılanma kanunlarını bütünü ile veya kapsamlı olarak değiştiren veya yürürlüğe koyan, tasarı veya teklifler özel görüşme yöntemiyle görüşülebilirler.

Madde dikkatlice incelendiğinde, hem Fransız Anayasasındaki anlamıyla bir organik yasadan söz edilemeyeceği ve bu nedenle, maddenin başlığı ile içeriği arasında bir uyumsuzluk bulunduğu, hem de maddenin kendi içinde çelişkili olduğu görülecektir:

\footnotetext{
${ }^{7}$ Yasanın kabulü için her iki meclisin de onayı gereklidir. Meclisler arasında uzlaşmazlık çıktığında sorunun çözülmesi için Meclisler arasında mekik yöntemi başlatılmaktadır. Meclisler metni bu durumda (genellikle) ikişer defa görüşürler. Uzlaşmazlık yine sürüyorsa Başbakan tarafından bir karma komisyon kurulması ve sorunun burada çözülmesi istenebilir. (Ayrıntı için bakınız: EROĞUL, 1997: 141-142)

${ }^{8}$ Anayasanın 61. maddesine göre diğer yasaların da yayınlanmadan önce Anayasa Konseyinin öndenetimine sunulmaları olanaklıdır. Ancak bunun için Cumhurbaşkanı, Başbakan ya da meclislerden birinin başkanının talebi gerekir.

92005 yılı değişikliği Anayasa Mahkemesinin önünde olduğundan bu incelemede ihmal edilmiştir.
} 
a. Maddenin başlığı ile içeriği arasında bir uyumsuzluk bulunmaktadır. Maddenin başlığı "Temel Kanunlar" olduğundan, okuyucu maddede temel yasa kavramının tanımını aramaktadır. Oysa madde temel yasanın ne olduğunu tanımlamadan, temel yasaların görüşülmesinde özel görüşme yönteminin uygulanabileceğini öngörmektedir. Dolayısıyla madde temel yasayı belirlemekten çok, temel yasa olduğuna karar verilen tasarı ya da teklifin özel görüşme yöntemiyle görüşülmesine olanak tanımaktadır. Diğer taraftan başlık "temel yasa" olmasına rağmen, maddenin içeriğine bakıldığında İçtüzük ve kimi başka yasaların da bu yöntemle görüşülebileceği görülmektedir. Dolayısıyla madde ne temel yasayı tanımlamakta, ne de başka yerde tanımlandığı varsayılan temel yasanın görüşme yöntemini belirlemektedir. Maddenin çizdiği çerçeve son derece belirsiz bir alanı gösterdiğinden, maddenin tanımlamasından, "temel yasayı" çıkarmak olanaklı değildir. Bu yasa kapsamında görüşülecek olan teklif ya da tasarıyı belirleyecek olan, TBMM'deki siyasal çoğunluktur. Çünkü Danışma Kurulunda uzlaşma sağlanamazsa -ki sağlanması da çok güçtürözel bir görüşme yönteminin uygulanmasına karar verecek olan TBMM üye tamsayısının beşte üç çoğunluğudur. Dolayısıyla beşte üç çoğunluk sağlanabildiği takdirde her yasa tasarısı ya da teklifinin özel bir yöntemle görüşülmesi olanaklıdır. Diğer bir anlatımla "temel kanunlarl" ve "ülkenin ekonomik ve teknolojik gelişimi" ibaresi her şeyi kapsayacak biçimde geniş yorumlanabilir: Yeter ki, Danışma Kurulunda uzlaşma ya da Genel Kurulda beşte üç çoğunluk sağlanabilsin. Nitekim, TBMM Genel Kurulu, 18. 10. 2001 tarihli Danıșma Kurulu önerisini kabul ederek bin maddenin üstündeki Medeni Kanun Tasarısını 10 bölüm halinde görüşmüştür. Medeni Kanunun, temel yasa olarak algılanıp özel görüşme yönteminin uygulandığ söylenebilir.

b. Maddedeki "Ülkenin ekonomik ve teknolojik gelişimi ile ilgili yeniden yapılanma kanunlarını bütünü ile veya kapsamlı olarak değiştiren veya yürürlüğe koyan" 10 cümlesi çok sayıda ve ciddi sayılabilecek mantık hatalarıyla doludur. Cümleyi mercek altına alınca bu hataları yakalamak olanaklıdır. Dikkat edilirse, "değiştiren" değil, "değiştirilecek olan" "yeniden yapılanma yasaları"dır. Değiştiren ise sıradan yasadır. Şu halde ortada bir yeniden yapılanma yasası vardır ve yasa koyucu bu yeniden yapılanma yasasını olağan bir yasayla değiștirmektedir. Oysa burada amaçlananın, bir yeniden yapılanma olduğu kuşkusuzdur. Dolayısıyla değiştiren yasanın yeniden yapılanma yasası olması gerekirdi.

c. Cümledeki bir başka ilginç nokta, bu yeniden yapılanma kanunlarını yürürlüğe koyan yasalar da özel yöntemle görüşülebilecektir. Yani ortada belirsiz bir yeniden yapılanma yasası vardır ve yine bu yasanın niye

\footnotetext{
${ }^{10} \mathrm{Bu}$ cümle 2003 y1lında 766 sayılı Kararla gerçekleştirilen değişiklikle madde metninden çıkarılmıştır.
} 
yürürlüğe sokulmadığ 1 belli değildir. ${ }^{11}$ Çıkarılan bir yasa, uygulanmadan beklemekte olan bu yasayı yürürlüğe koyacaktır. Yürürlüğe koyacak olan bu yasanın da, özel görüşme yöntemiyle görüşülmesi olanaklıdır.

Görüldüğü gibi madde baştan sona çelişkilerle doludur ve "temel kanun" belirsiz bir alanı ifade etmektedir. Dolaylstyla burada söz konusu olan belirli konularda düzenleme yapılması değil, özellikle uzun ya da çok maddeli yasalar için uzlaşma sağlanabiliyorsa uzlaşmayla, uzlaşma sağlanamıyorsa (varsa) beşte üç çoğunlukla özel bir görüşme yönteminin belirlenmesi ve bu yolla yasanın kısa süre içinde çıkarılmasıdır.

Anayasa Komisyonu tarafindan kabul edilen son metin, düzenlemenin bir temel yasa düzenlemesi olmadığını açıkça ortaya koymuştur.

Buradaki inceleme, sadece kod kanun ile temel kanunu ayrımını netleştirmek için yapılmıştır. Buradan çıkan sonuç, TBMM içtüzüğüne 1996 yılında eklenen 91. maddedeki temel kanunun, hiçbir anlamda kod kanun olmadığ ${ }^{12}$; bu maddedeki temel kanunun, Fransız Anayasasında bulunan organik yasayla hiçbir biçimde benzerlik taşımadığıdır. Türkiye'de önemli bazı yasaların yenilenmesi gereksinimi ve TBMM'nin çalışma süreleri içinde bu yasaların çıkarılma güçlüğü, TBMM'yi yasama sürecini kısaltma ve daha kısa sürede yasa çıkarma arayışı içine sokmuştur. 1996 yılında TBMM'nin parçalı yapısı ve bu yapı içinde bu tür yasaların çıkarılmasının neredeyse olanaksız olması karşısında, bir içtüzük değişikliğine gidilmiş ve birçok açıdan sorunlu olan bu madde İçtüzüğe eklenmiştir. Dolayısıyla bu maddede temel yasanın tanımlandığını düşünmek yanlıştır. Türk hukuk sisteminde tanımlanmış bir "temel yasa" kavramı olmamıştır. Maddeler, temel yasadan söz etmekte ancak temel yasanın ne olduğunu söylememektedir. Ayrıca maddeler, sadece tanımlandığı varsayılan temel yasanın görüşme yöntemine değil, içtüzük ve başka bazı yasaların da görüşme yöntemine ilişkindir.

Burada belirtmek gerekir ki, temel yasa diye bir kavram olacaksa, temel yasalar anayasa gibi bir üst hukuk normunda belirlenmeli ve bunların özel

\footnotetext{
${ }^{11}$ Oysa teorik olarak yürürlük maddesi olmayan bir yasanın çıkarılması olanaklı değildir.

12 Araç ve İba, "Kod(Temel)-Çerçeve(Taşıyıcı) Kanun" başlığında kod ve temel kanunu özdeşleştirmektedirler(2003: 44). Oysa bu tür bir özdeşlik bulunmadığını onların yaptı̆̆ 1 incelemeden de çıkarmak olanaklıdır. Çünkü söz konusu başlık altında kod yasa-çerçeve yasa ayrımını ortaya koymakta ve kod yasa ile temel yasanın aynı şey olduğunu söylememektedirler. Ayrıca hemen izleyen başlık altında temel yasayı incelemektedirler. Bu da kod yasa ile temel yasayı aslında aynı anlamda kullanmadıklarının göstergesidir. Dahası "temel Kanun" başlı̆̆ 1 altında "Aslında, içtüzük koyucu tarafindan yapay olarak verilen bu ad, kod kanunlarla karışıklığa yol açıyordu." diyerek temel kanunla kod kanunun aynı şey olmadığını kabul etmektedirler. Ancak Araç ve İba'nın bu konuda yeterince berrak olduklarını düşünmek güçtür. Çünkü kod yasalara örnekler verirken temel yasa örnekleri vermekte ve aslında temel yasalarda bulunması gereken özellikleri kod yasalarda aramaktadırlar.
} 
görüşme yöntemi de bu üst hukuk normunda belirtilmelidir. Örneğin ceza yasası, medeni yasa, borçlar yasası, ticaret yasası, iş yasası, sendikalar yasası, siyasal partiler yasası, seçim yasası gibi toplumsal-siyasal ve ekonomik alanda belirleyici olan yasalar, temel yasa olarak sayılabilir. Tekrar etmek gerekirse, Türk hukuk sisteminde bu tür bir "temel yasa" anlayışı olmadığ gibi, AYM tarafından bugüne kadar iptal edilen "temel yasa" düzenlemelerinin de burada söz edilen temel yasa anlayıșı ile bir ilgisi bulunmamaktadır. ${ }^{13}$ Ancak temel yasa kavramının, kavramsal bir analiz açısından tanımlanması zorunludur. Bu makalede "temel yasa" kavramı, "toplumsal-siyasal ve ekonomik alanda belirleyici olan yasa" biçiminde tanımlanmıştır.

Temel yasa kavramını böylece belirledikten sonra, şimdi kod yasa çerçeve yasa ayrımına geçilebilir.

Araç ve İba kod yasayı şöyle tanımlamaktadırlar: "Kendi başına bir alanı düzenleyen, mevcut herhangi bir kanunda değişiklik yapmayan kanunlar..."(2003: 44). Bu tanımlama kod yasanın iki özelliğini öne çıkarmaktadır.

(1) Kendi başına bir alanı düzenleme,

(2) Mevcut bir yasada değişiklik yapmama.

Bu iki nitelik de doğru seçilmiştir. Gerçekten de kod yasa, yürürlükteki yasalarla düzenleme konusu olmamış bir alanda kendi başına düzenleme yapmakta ve bu düzenleme yürürlükteki bir yasayı değiştirerek değil yeni bir yasayla yapılmaktadır. Ancak Araç ve İba doğru yapılan bu tanımın devamında yanlış anlamalara yol açabilecek açıklamalarda bulunmaktadırlar. Araç ve İba tanımın devamında şunları söylemektedirler:

"Örnek olarak, Türk Medeni Kanunu ve Türk Ceza Kanunu gösterilebilir. Kod Kanunu'nda sırasıyla amaç, kapsam, tanımlar, kuruluş, organlar, nitelikler, görev, yetki, sorumluluklar, cezai hükümlerle, tüzük, yönetmelik, ek maddeler, kaldırllan hükümler, geçici hükümler, yürürlük ve yürütme maddesi hükümleri yer alır ..." (2003: 44).

Burada verilen örnekler ve kod yasada bulunması gereken niteliklere bakıldığında, gerçekte, kod yasadan değil, temel yasadan söz edildiği görülecektir. Burada temel yasalarla kod yasalar özdeşleştirilmiş ve dolayısıyla kod yasanın alanı daraltılmıştır. Aslında şunu kabul etmek gerekir ki, bütün temel yasalar aynı zamanda kod yasadır. Bu nedenle yukarıdaki ifadeler ilk bakışta doğru gibi görünmektedir. Ancak kod yasalar

13 Örneğin İsveç Anayasasında üç temel konuda temel yasa çıkarılacağı öngörülmektedir. Anayasa, basın yasası ve ardıllık yasası. İsveç Anayasası bu yasaların görüşülmesinde referandumu içeren özel görüşme yöntemleri getirmektedir. 
temel yasalardan ibaret değildirler. Kod yasa $\geq$ Temel yasa. Örneğin il ya da ilçe kuran yasalar da kod yasadır ama bu yasalarda yukarıda sayılan amaç, kapsam, tanımlar, yönetmelik vb. birçok madde bulunmaz. Dolayısıyla bu yasalar kod yasadır ama temel yasa değildir. Kod yasada, bu açıdan daha belirleyici olan, yürürlükteki bir yasada değișiklik yapmama niteliğidir. Daha açık söylemek gerekirse, yukarıda sayılan özelliklere uygun kod yasalar bulunabileceği gibi, bu özellikleri taşımayan kod yasalar da vardır. Ancak bu örnekler ve özellikler, temel yasalara tümüyle uymaktadır. Dolayısıyla burada kod yasa tanımlanmaya çalış1lırken, aslında temel yasalar tanımlanmıştır. Söylenenlerin ilk bakışta doğru gibi görünmesinin nedeni, bütün temel yasaların aynı zamanda kod yasa olmasıdır.

Şu halde hem temel yasalar, hem de kod yasalar yürürlükteki bir yasada değişiklik yapmazlar ve bir alanı başından sonuna ayrıntılı olarak düzenlerler. Ancak temel yasa, toplumsal-siyasal ve ekonomik alanda belirleyici olmak zorunda iken kod yasanın bu tür bir belirleyiciliğinin bulunması gerekmez. $\mathrm{Bu}$ nedenle de temel yasada, amaç, kapsam, tanımlar...vb. maddelerin bulunması gerekirken, kod yasada bu maddeler bulunmayabilir.

Kod yasanın yukarıdaki özelliklerinden hareketle çerçeve yasanın tanımına ulaşmak olanaklıdır: Yürürlükteki bir yasada değişiklik yapan yasa çerçeve yasadır ${ }^{14}$. İba ve Bozkurt da "öteki kanunlara göndermeler yaparak onlarda ek ve değişiklikler yapan kanun"u çerçeve yasa veya taşıyı1 yasa biçiminde tanımlamaktadırlar (2003: 51). Burada "öteki kanunlara" ibaresi ile kastedilen "kod kanunlara" dır. Yoksa çerçeve yasanın bir başka çerçeve yasayı değiştirmesi sözkonusu olmaz. Dolayısıyla kod yasayı, "yürü̈rlükteki bir yasada değişiklik yapmayan yasa" ve "çerçeve yasayı da, kod yasayı değiştiren yasa” biçiminde tanımlamak gerekir. Örnek vermek gerekirse, medeni yasa, hem temel yasa hem de kod yasadır. Oysa bir ilin adının değiştirilmesine ilişkin yasa, kod yasa iken temel yasa değildir. Çünkü bu yasa yürürlükteki herhangi bir yasada değişiklik yapmamakta, yeni bir yasayla ilin adını değiştirmektedir. Bu nedenle kod yasadır. Ancak bu yasa, toplumsal-siyasal ve ekonomik alanda herhangi bir etkiye sahip değildir ${ }^{15}$. Bu nedenle bu kod yasa, temel yasa değildir.

Burada son olarak Araç ve İba'nın kod yasalara örnek olarak gösterdikleri, -ancak aslında temel yasa örnekleri olan- yasalarda bulunmas1 gereken maddelerle ilgili son bir noktaya daha dikkat çekmek gerekir. Araç ve İba,

\footnotetext{
14 Çerçeve yasa yürürlükteki bir yasayı değiştirmektedir. Yürürlükteki yasanın hangi maddesinin (fikrasının, bendinin, cümlesinin vs.) değiştirildiğini gösteren bir çerçevesi bulunmaktadır. Bu nedenle çerçeve yasa aslında, "maddeleri çerçeveli olan" yasadır.

${ }^{15}$ Aslında bu yasa maddi anlamda bir yasa da değildir; sadece yasama organı tarafindan çıkarılmış olması nedeniyle biçimsel anlamda yasadır.
} 
"Kod Kanunu'nda sirasıyla amaç, kapsam, tanımlar, kuruluş, organlar, nitelikler, görev, yetki, sorumluluklar, cezai hükümlerle, tüzük, yönetmelik, ek maddeler, kaldırllan hükümler, geçici hükümler, yürürlük ve yürütme maddesi hükümleri yer alır ..."(2003: 44).

Cümlesinde, kod yasada ek madde bulunması gereğinden söz etmektedirler. Yukarıda da gösterildiği gibi, kod yasalarda, yürürlük ve yürütme maddeleri dışında bu maddelerin hiçbirinin bulunması gerekmez. $\mathrm{Bu}$ maddelerin tümünün (ek madde dışında) ya da bir kısmının bulunduğu kod kanunlar olabilir. Ancak, yürürlük ve yürütme maddeleri dişında, bu maddelerin hiçbiri olmadan da kod yasa düzenlenebilir. Ya da bu maddelerin bir kısmının bulunduğu kod yasalar olabilir. Örneğin başka yasaların hükümleri kaldırılmıyorsa kaldırılan hükümler, yaptırım düzenlenmiyorsa cezai hükümler yer almaz vs. Öte yandan, kod yasalarda "ek maddeler" bulunmaz. Diğer bir anlatımla kod yasalarda, zorunlu olmamakla birlikte, ek madde dışında, yukarıda sayılan bütün maddelerin bulunması olanaklıdır. Çünkü ek madde, yürürlükteki bir yasaya yeni madde eklenmek istendiğinde, yürürlükteki yasanın madde sıralamasını bozmamak için başvurulan bir yoldur. $\mathrm{Bu}$ alanda belirli bir düzenleme yoksa ve yeni bir düzenleme getiriliyorsa, madde siralamasının bozulması da söz konusu olmaz. Dolayısiyla kod yasalarda ve temel yasalarda ek madde bulunmaz. Nitekim Araç ve İba da metnin hemen devamında, kod yasada çerçeve madde ve ek madde bulunmadığını ifade etmektedirler (2003: 44). Dolayısıyla buradaki "ek maddeler" ibaresinin sehven yazıldığını kabul etmek gerekir. Son olarak şunu belirtmek gerekir ki, temel yasaların tümünde, yukarıda sayılan bütün maddelerin bulunması gerekmez.

Kod yasa-çerçeve yasa ayrımının pratikte çok önemli bir sonucu vardır. $\mathrm{Bu}$ ayrım, kod yasa ve çerçeve yasanın farklı biçimde işaretlenmesi ve işlenmesi yoluyla farklı türdeki yasaların tanınmasına olanak verir. $\mathrm{Bu}$ ayrımın farkında olunmadığında ise sorunlu durumların oluşması söz konusudur. $\mathrm{Bu}$ sorunlu durumların ne olduğunun açıklanmasından önce kod yasaların ve çerçeve yasaların yerlerine nasıl işlenmesi ve nasıl işaretlenmesi gerektiği konusunda bir bilgi vermek gereklidir.

Kod kanunlarda madde numaraları,

"Madde 1-,

Madde 2,

Madde 3," ...biçiminde gösterilmektedir. Bu yazım biçimi son derece olağandır. Çünkü maddelerin yazımında da ilk harf büyük olmak üzere madde hükümleri küçük harflerle yazılmaktadır. Dolayısıyla bütün kod yasalarda maddelerin bu biçimde gösterilmesi gerekir. 
Çerçeve yasalarda ise, kod yasalar ile çerçeve yasaların maddeleri birbirine karışmasın diye madde numaraları "MADDE 1-, MADDE 2-, MADDE 3-“ ...biçiminde gösterilmelidir. Böylece okuyucu metne baktığında yasanın çerçeve yasa $\mathrm{m} 1$ yoksa kod yasa mı olduğunu; yasa, çerçeve yasa ise hangi maddenin çerçeve yasanın maddesi olduğunu hangisinin değiștirilmekte olan kod yasanın maddesi olduğunu kolaylıkla görebilecektir. Örneğin,

"Madde 1. A Üniversitesi kurulmuştur.

Madde 2. Bu Kanun, yayımı tarihinde yürürlüğe girer.

Madde 3. Bu Kanun hükümlerini Bakanlar Kurulu yürütür.”

biçimindeki bir yasa kod yasadır ve bunun kod yasa olduğu maddenin küçük harflerle yazılmasından da anlaşılmaktadır.

Çerçeve bir yasada ise,

"MADDE 1. - 28.5.1988 tarihli ve 3466 say1lı Uzman Jandarma Kanununun 4 üncü maddesinde yer alan "ortaokul" ibaresi "lise" olarak değiştirilmiştir.

MADDE 2. - 3466 sayılı Kanunun 6 ncı maddesi aşağıdaki şekilde değiştirilmiştir.

"Madde 6. - Uzman jandarmalar, ... eğitimine tâbi tutulabilir."

Böylece okuyucu metne bakar bakmaz MADDE 1 ve MADDE 2' biçiminde büyük harflerle yazılan maddelerin çerçeve yasanın maddeleri olduğunu ve kod yasa olan 3466 sayılı yasanın 4. maddesinin kısmen, 6 . maddesinin ise tümüyle değiştiğini anlayacaktır. ${ }^{16}$

Kamu kurum ve kuruluşlarının resmi olarak yasaları izledikleri ve Başbakanlık tarafindan her üç ayda bir güncelleştirilen "Kanunlar Külliyatı"na çerçeve yasalar işlenirken, çerçeve yasaların "çerçevesi" buraya aktarılmamakta, kod kanunlarda yapılan değişiklikler değiştirilmiş biçimiyle metne işlenmekte ve bu değişikliği yapan çerçeve yasanın tarih ve sayısı parantez içinde gösterilmektedir. Dolayısıyla değiştirilen maddenin küçük harflerle yazılması, eskiden de küçük harflerle yazılmış olan madde numaralarının sistematiğinin korunması ile sonuçlanacaktır. Ancak kod yasaya işlenmesi gereken madde çerçeve yasanın maddesi ise, buradaki "Madde" sözcügünün büyük harflerle işlenmesi gerekir. Dolayısıyla ortadaki sistem uygulayıcıların isteklerine bırakılmış bir sistem olarak karşımızda durmaktadır. Başbakanlıktaki ilgili birim, bütün madde numaralarını küçük harflerle yazdığından, kod kanunlar açısından doğru ancak kod kanuna

${ }^{16}$ Çerçeve yasa kullanılarak kod yasada yapılan değişikliğin belirginleştirilmesi için yapılan bir diğer işaretleme, yapılan değişikliğin tırnak işareti içine alınmasıdır. Böylece kod yasaya işlenecek kısım net olarak görünecektir. 
çerçevesiyle birlikte işlenmesi zorunlu olan çerçeve yasa maddelerinin işlenmesi açısından yanlış bir işlem yapmış olmaktadır.

Diğer taraftan TBMM'de giderek güçlenen eğilim ise, Başbakanlıktakinin tersine bütün madde numaralarının büyük harflerle yazılmış "MADDE" sözcüğü ile ifade edilmesidir. Örneğin 19/11/2003 tarihli ve 5003 sayılı Yasa bir kod yasa olmasına rağmen madde sözcükleri büyük harflerle yazılmıştır. Yine 10/12/2003 tarih ve 5016 sayılı çerçeve yasa, 17/7/1963 tarihli ve 278 sayılı kod yasaya bir geçici madde eklemektedir ve metne bakıldığında hem çerçeve yasadaki, hem kod yasadaki "madde" sözcüğünün büyük harflerle yazıldığı görülmektedir. Ancak bu yanlışlığa rağmen, düzenleme, Kanunlar Külliyatına işlenirken doğrusu yapılmış ve madde sözcükleri küçültülmüştür. Bu da Başbakanlığın ilgili biriminin, yukarıda aktarılan "Madde küçük harflerle yazılır." anlayışından kaynaklanmaktadır. Yukarıda açıklandığı gibi, çerçeve kanun maddelerinin çerçevesiz olarak kod kanuna işlenmesi durumunda, bu anlayış, olması gereken doğru sonucu vermektedir. Ancak çerçeve kanun maddesinin, kod kanuna çerçeveli olarak işlenmesinin zorunlu olduğu durumda, "Madde küçük harflerle yazllır." uygulaması yanlış sonuçlar vermektedir.

Bütün bu söylenenler şöyle bir soru üretmektedir: Kod kanuna çerçeve kanun maddesinin çerçeveli olarak eklenmesi zorunluluğu nereden kaynaklanmaktadır? Bu zorunluluk şu durumlarda ortaya çıkmaktadır. Kod kanunun maddeleri içinde birbirine gönderi yapan maddeler bulunabilir. Örneğin ceza yasasında şöyle bir hüküm bulunabilir:

"Madde X.- ...Bu madde hükmüne aykırl davrananlar bu Yasanın dördüncü maddesi hükümlerine göre cezalandırllırlar."

Böylece aynı hükmü bir daha yazmaya gerek kalmadan, ilgili ceza hükmünün işlemesi sağlanır. Burada "bu Yasanın" ifadesi hiç kuşkusuz ceza yasasını göstermektedir. Bu konuda herhangi bir sorun bulunmamaktadır.

Bir çerçeve yasa ile kod yasada değişiklik yapılarak benzer bir hüküm düzenlenebilir. Örneğin bir çerçeve yasayla yukarıda aktardığımız hüküm şöyle değiştirilebilir:

'MADDE 1-y tarihli ve z sayılı Ceza Yasasının X. maddesi aşağıdaki biçimde değiştirilmiştir.

"Madde X.- .../Bu madde hükmüne aykırl davrananlar bu Yasanın sekizinci maddesi hükümlerine göre cezalandırılırlar.",

Burada da herhangi bir sorun bulunmamaktadır. Çünkü çerçeve yasayla kod yasada değişiklik yapılmış ve kod yasanın hükmü değiştirilmiştir. " $b u$ Yasanın" ifadesi, çerçeve yasayı değil, yine kod yasa olan ceza yasasını göstermektedir. Dolayısıyla X. maddeye aykırı davrananlar artık dördüncü maddeye göre değil, sekizinci maddeye göre yaptırıma tabi tutulacaklardır. 
Sorunlu olan durum şudur: Çerçeve yasanın maddeleri kimi zaman değişiklik yaptığı kod yasaya değil kendi maddelerine gönderi yapmaktadır. $\mathrm{Bu}$ durumda madde kod yasanın herhangi bir bölümüne işlenememektedir. Ancak çerçeve yasanın maddeleri kod yasaya işlenerek işlemeye başladıklarından, bu tür gönderi yapan maddeler boşlukta kalmaktadırlar. Konunun daha iyi anlaşılması için bir örnek, 1982 Anayasasına eklenen "GEÇİCI MADDE"dir" ${ }^{17}$ 7.11.1982 tarihli ve 2709 say1l Türkiye Cumhuriyeti Anayasasında 3.10.2001 tarihinde 4709 sayılı Yasa ile çeşitli değişiklikler yapılmıştır. Bu değişikliklerin biri dışında tümü ilgili maddelere işlenmiştir. Teknik açıdan sorunlu gibi görünen madde, bir geçici maddedir. Söz konusu geçici madde hükmü şöyledir:

"GEÇICII MADDE.- A) Bu Kanunun 24 üncü maddesi ile Anayasanın 67 nci maddesine son fikra olarak eklenen hüküm bu Kanunun yürürlüğe girmesinden sonra yapılacak ilk genel seçimde uygulanmaz.

B) Bu Kanunun 28 inci maddesi ile Anayasanin 87 nci maddesinde yapılan değişiklik, bu Kanunun yürürlük tarihinden önce, Anayasanın 14 üncü maddesindeki fiilleri işleyenler hakkinda uygulanmaz."

Bu maddedeki " $b u$ Kanunun" ibareleri, hiç kuşkusuz, Anayasayı değil Anayasayı değiştiren çerçeve kanunu ifade etmektedir. Dolayısıyla madde her ne kadar Anayasanın 67 ve 87 . maddelerindeki kuralların belirli durumlar ve kişiler için istisnai olarak uygulanmamasını emrediyorsa da ve bu anlamda Anayasa hükmüyse de, teknik anlamda, Anayasanın kuralı değildir. "Bu Kanun" ibaresi ile Anayasa anlaşılırsa, "Bu Kanunun 24 üncü maddesi ile" ibaresinin de Anayasanın 24 üncü maddesini ifade etmesi gerekir. Oysa Anayasanın 24. maddesi din ve vicdan hürriyetini düzenlemektedir ve maddede düzenlenen konuyla ilgisi yoktur. Dolayısıyla "Bu Kanunun 24 üncü maddesi ile" ibaresi, duraksamaya yer bırakmaksızın, 4709 sayılı çerçeve yasanın hükmüdür. İşte sorun, kod yasayla ilişkili olan ancak çerçeve yasaya gönderide bulunan hükümlerdir. Bu hükümlerin kod yasada görünmesi zorunluluktur, ancak bunların kod yasa hükmü olarak işlenmeleri olanaksızdır. Kod yasa- çerçeve yasa ayrımı ve bu ayrıma dayalı yazım biçimi, sorunu kökünden çözecek niteliktedir. Uygulamada bu tür maddeler kod kanunun sonunda ayrı bir bölüme alınmakta ve "Ana ${ }^{18}$ Kanuna İşlenemeyen Hükümler" başlığı altında toplanmaktadır. Bu tür hükümler farklı çerçeve yasa hükümleri ise birden fazla numarasız ana yasaya işlenemeyen hükme rastlanmaktadır. Oysa "Ana Kanuna İşlenemeyen Hüküm" başlığı kendi içinde çelişkilidir. Ana kanuna ya da kod kanuna işlenemeyen hüküm ne demektir? Teorik olarak bir hüküm ya yasanın

17 Anayasa ile yasalar arasında, çerçeve yasaların kod yasaya işlenmesi bakımından bir farklılık bulunmadığından, daha çarpıcı olması bakımından anayasayı değiştiren bir çerçeve kanun örnek olarak seçilmiştir. Bu bağlamda anayasa kod yasa, onu değiştiren yasa ise çerçeve yasadır.

${ }_{18}^{8}$ Buradaki “ana” sözcüğü burada kullanılan“kod” anlamında kullanılmaktadır. 
hükmüdür ve ilgili yasaya işlenir ya da hükmü değildir ve dışarıda kalır. Şu halde bu tür maddelerin kod yasaya işlenmesi zorunludur ve bunların bu tür bir başlık altında verilmesi doğru değildir. Yapılması gereken şey çok basittir: Çerçeve yasaya gönderi yapan kod yasa hükümlerini, çerçeve yasadan oldukları gibi aktarmak. Çerçeve yasada başlıkları "MADDE" biçiminde büyük harflerle yazılan bu maddeler, çerçeve yasadan aynen aktarılmakla, küçük harflerle yazılmış kod yasa hükümlerinden ayrılmış olacaktır. Böylece okuyucu metne bakar bakmaz, hangi maddenin kod yasa hükmü olduğunu ve hangi maddenin kod kanunda bulunması gereken çerçeve yasa hükmü olduğunu görecektir. Böyle bir durumda "ana kanuna işlenememek" gibi acayip bir durum ortaya çıkmayacaktır.

Başbakanlığın ilgili biriminin "madde" sözcüğünü büyük harflerle yazmak gibi bir yöntemi olmadığı için bu madde de küçük yazılmış ve ana kanuna işlenemeyen hükümler başlığı altında verilmiştir. TBMM'de bastırılan Anayasaya bakıldığında ise bütün geçici maddelerin büyük harflerle diğer maddelerin ise küçük harflerle yazıldığı görülmektedir. Böyle bir yazım farklılığının ise hangi ölçüte göre yapıldığı belli değildir. AYM verdiği bir kararında (E. 2000/37, K. 2000/14, G. 15.6.2000),

"Sözü edilen maddenin "geçici madde" olarak adlandırılmış bulunması etki ve dĕger bakımından...öteki maddeler(in)den daha zaylf ve önemsiz olduğu biçiminde yorumlanmasina neden olamaz"

diyerek son derece doğru bir saptama yapmıştır. Dolayısıyla maddelerin farklı adlarla adlandırılmış olması etki ve değer bakımından maddelerin farklı olduğu sonucunu doğurmayacağına göre, bu tür bir yazım farklılaştırmasının gerekçesi ne olabilir?

Sonuç olarak bu makalede, maddeleri küçük ya da büyük harfle yazmanın bir işlevinin olduğu düşünülmektedir. Kural, her durumda çerçeve yasa maddelerin büyük harfle, kod yasa maddelerinin ise küçük harfle yazılmasıdır. Bu kural hem yukarıda tanımlanan çerçeve yasa ile kod yasa arasında kolaylıkla ayrım yapılmasını sağlayacak, hem de "ana kanuna işlenememek" gibi garip bir durumun oluşmasını önleyecektir. Ancak bu kuralın uygulanabilmesi için, bu sistemin yasa teklifi ya da tasarısının hazırlanması aşamasından Kanunlar Külliyatına işlenmesi aşamasına kadar korunması gerekir. Aksi takdirde Başbakanlıktaki ya da TBMM'deki uygulayıcıların takdirlerine bağlı olarak maddeler büyük veya küçük ya da hem büyük, hem küçük harflerle yazılacak ve bu yazımın herhangi bir işlevi olmayacaktır. Oysa bu makalede ortaya konan ayrım son derece işlevseldir. 


\section{KAYNAKÇA}

- ARAÇ, İbrahim ve Şeref İBA(2003), “Türkiye'de Yasa Önerisi Hazırlama ve Norm Koyma Tekniği ve Yasamacı Mesleğinin Nitelikleri Üzerine", A. Ü SBF Dergisi, 58/3

- BAKIRCI, Fahri(2000), TBMM'nin Calıșma Yöntemi, (Ankara: İmge Kitabevi)

- BAKIRCI, Fahri(2004), "Yasalarda ve Yasa Maddelerinde Geçicilik Üzerine", Meclis Bülteni, say1: 111.

- EROĞUL, Cem(1997), Căğdaș Devlet Düzenleri, (Ankara: İmaj Yayınları)

- $\quad$ GÖZLER, Kemal(2004), Türk Anayasa Hukuku Dersleri, (Bursa: Ekin Kitabevi Yayınları)

- $\quad$ GÜRBÜZ, Yaşar(1981), Anayasalar, (İstanbul: Filiz Kitabevi)

- İBA, Şeref ve Rauf BOZKURT(2004), 100 Soruda Parlamento: Türk Parlamento Hukukuna Giriș, (Ankara: Nobel Yayın Dağıtım).

- KİLİ, Suna ve Şeref Gözübüyük(1985), Türk Anayasa Metinleri, (Ankara: Türkiye İş Bankası Yayınları)

- $\quad$ SABUNCU, Yavuz(2002), Anayasaya Giriș, (Ankara: İmaj Yayınları)

- TEZİÇ, Erdoğan(2003), Anavasa Hukuku (İstanbul: Beta Basım).

- $\quad$ E. 2000/37, K. 2000/14, G. 15.6.2000.

- $\quad$ E. 2001/129, K. 2002/24, G. 31.1.2002.

- $\quad$ E. 2003/30, K. 2003/38, G. 29.4.2003.

- Sira Sayısı no: 161, 22. dönem, 3. yasama yı11 